DEPÓSITO LEGAL ZU2020000153

Esta publicación científica en formato digital

es continuidad de la revista impresa

ISSN 0041-8811

E-ISSN 2665-0428

Revista

de la

Universidad

del Tunlia

Fundada en 1947

por el Dr. Jesús Emrique Lossada

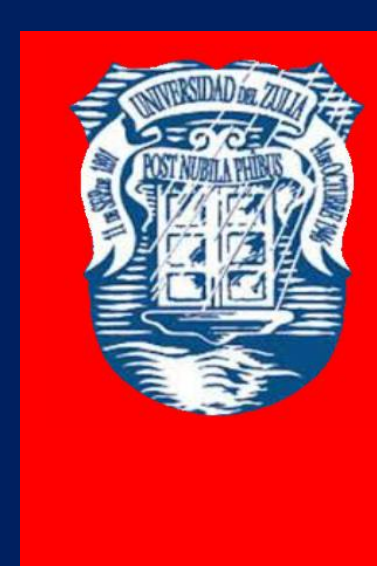

Ciencias

Sociales

y Arte

Aกัต 11 No 31

Septiembre - Diciembre 2021

Tercera ípoca

Maracailbo-Venezuela 


\title{
Digital technologies in the organization of the educational process in the teachers' training system
}

\author{
Ekaterina V. Vezetiu * \\ Igor O. Petrishchev ** \\ Valery G. Shubovich *** \\ Oxana O. Varnavskaya **** \\ Maxim M. Kutepov $* * * *$
}

ABSTRACT

The current stage of political, economic and social development is characterized by the active introduction of digital technologies, which have become an integral part of society. The education sector has not been on the sidelines. Today, the field of education, including professional, includes the use of various electronic media and resources. The need to build a digital educational space is determined by a series of factors, among which the development of the digital economy and its requirements for the training of specialists predominate. Digital technology has transformed learning and teaching. At the center of the modern stage of technological development for the foreseeable future, smart technologies will continue to play a dominant role. The purpose of the article is to analyze the impact of digital technology on the quality of training of students in continuing education courses. A study among students of continuing education courses has established the impact of digital technology on the quality of training of students of continuing education courses. The essence of digitization in education is highlighted in the article, the details of the digital presentation of information are determined, the characteristics of the implementation of digital technologies are revealed, and their capabilities are noted.

KEY WORDS: advanced training courses, digitalization, digital technologies, students, teachers.

* V.I. Vernadsky Crimean Federal University, Prospekt Vernadskogo 4, Simferopol, Russia, https://orcid.org/0000-0002-2548-318X

** Uiyanovsk State University of Education, pl. Lenina, 4/5, Ulyanovsk, Russia, https://orcid.org/0000-0002-2247-2303

***Uiyanovsk State University of Education, pl. Lenina, 4/5, Ulyanovsk, Russia, https://orcid.org/0000-0003-3512-7653

**** North-Caucasus Federal University, Stavropol, Russia, https://orcid.org/0000-0003-3953-3595

***** Minin Nizhny Novgorod State Pedagogical University, Uljanov street, 1, Nizhny Novgorod, Russia, https://orcid.org/0000-0002-5397-6168 


\section{Las tecnologías digitales en la organización del proceso educativo en el sistema de formación docente}

\section{RESUMEN}

La etapa actual de desarrollo político, económico y social se caracteriza por la introducción activa de tecnologías digitales, que se han convertido en parte integral de la sociedad. El sector de la educación no se ha mantenido al margen. Hoy en día, el campo de la educación, incluida la profesional, incluye el uso de diversos medios y recursos electrónicos. La necesidad de construir un espacio educativo digital viene determinada por una serie de factores, entre los que predominan el desarrollo de la economía digital y sus requisitos para la formación de especialistas. La tecnología digital ha transformado el aprendizaje y la enseñanza. En el centro de la etapa moderna de desarrollo tecnológico en el futuro previsible, las tecnologías inteligentes seguirán teniendo un papel dominante. El propósito del artículo es analizar el impacto de la tecnología digital en la calidad de formación de los estudiantes de cursos de educación continua. Un estudio entre estudiantes de cursos de educación continua ha permitido establecer el impacto de la tecnología digital en la calidad de la formación de los estudiantes de cursos de educación continua. La esencia de la digitalización en la educación se resalta en el artículo, se determinan los detalles de la presentación digital de la información, se revelan las características de la implementación de tecnologías digitales y se señalan sus capacidades.

PALABRAS CLAVE: cursos de formación avanzada, digitalización, tecnologías digitales, estudiantes, profesores.

Introduction

Modern society is characterized by active development of technological progress, which has led to the emergence of a large amount of information, artificial intelligence, virtual and augmented reality, and other various phenomena related to digital technologies (Cirdan, 2019) .The Government of the Russian Federation approved the state program "Digital Economy", according to which by 2024 the share of specialists with competencies in the field of information technology at the global level, as well as the proportion of the population with digital skills, should increase significantly (Aleksieienko-Lemovska, 2019). The notion of digitalization, meaning widespread introduction of digital technologies in various spheres of society, including those in education (Andriushchenko, 2018). Digitalization is characterized not only by the translation of paper training materials into electronic form, but by the formation of a whole range of interactive multimedia resources (Bulayeva et al., 2019). 
REVISTA DE LA UNIVERSIDAD DEL ZULIA. 3e época. Año 11 N 31, 2020 Ekaterina V. Vezetiu et al. /// Digital technologies in the organization of the educational process ...450-460

DOI: http://dx.doi.org/10.46925//rdluz.31.28

Fundamental reformation processes in the field of education made it possible to introduce them into the learning process in higher education institutions (Chirva \& Chirva, 2018).

Digital technologies have expanded the capabilities of both students and teachers, and contribute to the resolution of many important issues related to training, retraining and advanced training (Pisarenko, 2019). Since the modern educational paradigm focuses on continuing education and the need to improve professional knowledge, today high schools provide various continuing education courses, the main students of which are adults. Their training has its benifits, one of the main elements of which is the impossibility of $s$ regular visits to full-time employment by reason of employment. Digital technologies allow you to make the learning process affordable and quality taking into account this feature. The quality of the educational process not only does not decline, but also becomes higher. The implementation of digital technologies provides benefits for both students and teachers themselves (Myalkina, 2019). This article considers the implementation of digital technologies in the process of training refresher course students "Actual problems of modern education" and "Management in Education" Institute directed professional education.

\section{Theoretical framework}

Influence of digital environment (tsifrovizirovanoy) on educational process is the focus of many of today's scientists. Digital technology has transformed learning and teaching. At the core of the modern stage of technological development in the foreseeable future, smart technologies will retain a dominant role.

According to the researchers, most digital technologies have didactic properties, including:

- free search of information on the global Internet;

- individualization - the ability to personalize the needs and characteristics of each student (the choice of the method of presentation of the material, the level of complexity and pace of work, and so on);

- ensuring a high level of interactivity in the absence of full-time interaction (preserving the communication of the subjects of the educational process);

- complex inclusion process with by learning various channels of perception (hearing, sight); 
REVISTA DE LA UNIVERSIDAD DEL ZULIA. $3^{a}$ época. Año 11 N 31, 2020 Ekaterina V. Vezetiu et al. /// Digital technologies in the organization of the educational process ...450-460

DOI: http://dx.doi.org/10.46925//rdluz.31.28

- the ability to freely move through the text (the presence of hyperlinks, collapse and deployment of information) (Vaganova et al., 2019a).

The advent of digital pedagogy, to ensure Vaeth improving the quality of education through the use of various technical means, computers and e-learning programs (Pichugina et al., 2019). If the traditional approach to the educational process provided for the direct transfer of knowledge from the teacher to the student, today the student independently studies a large amount of information with the counseling role of the teacher (Vaganova et al., 2019b). Digital tools allow students to develop the ability to accurately formulate requests and thereby find the necessary answers, choose relevant material, and implement creative projects using electronic tools, for example, video and audio (Raven, 2017). Students learn modern ways of presenting information. This is an important skill for educators taking advanced training courses (Pliushch, 2018). At the same time, teachers have the opportunity to transfer part of the educational materials to digital media (s) or to an electronic educational platform (Vaganova et al., 2019c).

Researchers note among the features of digital information:

- the possibility of various ways of presenting it (Osadchenko, 2019);

- increasing the visibility of training materials (Oros et al., 2018);

- copying and distribution of information without losing its accuracy and reliability;

- an increase in its transmission rate.

Digital technologies expand the educational process, make it more fulfilled and effective (Donetskova, 2019).

Digitalization in education contributes to the formation of a holistic environment by the teacher in which he creates the necessary technological (Filchenkova et al., 2019), instrumental, methodological, documentary support, which allows to build an effective educational process (Tsarapkina.et al., 2019a). On replacing traditional learning tools come innovative (Tsarapkina.et al., 2019b). According to researchers, these include electronic textbooks, interactive whiteboards, document cameras, multimedia installations, and many others). Among the digital technologies relevant for implementation in the educational environment, scientists distinguish:

- artificial intelligence technologies (contribute to the construction of individual educational routes by focusing on the needs of a particular student) (Grigoriev et al., 2019); 
REVISTA DE LA UNIVERSIDAD DEL ZULIA. 3e época. Año 11 N 31, 2020

Ekaterina V. Vezetiu et al. /// Digital technologies in the organization of the educational process ...450-460

DOI: http://dx.doi.org/10.46925//rdluz.31.28

- virtual and augmented reality technologies (allow visualizing educational processes to form competencies in a playful way);

- Big Data allows you to track the learning process of each individual student, to discover his successes and failures.

\section{Methodology}

At the Institute of Guided Professional Education, we conducted a study that allowed us to establish the influence of digital technologies on the quality of training of students in the framework of continuing education courses: "Actual problems in education" and "Management in education".

The study involved 4 study groups, the total composition of which was divided into 2 groups. In the preparation of the first group of students of 45 people, the training was conducted in a more traditional way, without the introduction of advanced digital technologies. In the training of the second group (44 people), various digital technologies were actively used.

As the final event is the protection of design works. An analysis was made of students' grades for completed projects. Statistical analysis of the results has allowed to establish that the second group has higher scores.

A survey of students of continuing education courses "Actual problems in education and" and "Management in education" was also conducted. Including a survey $l$ a number of questions about the use of digital technologies in the preparation of the project. In the process of statistical processing of the results, an interconnection of variables was established that affect the results of respondents' answers.

\section{Results and discussion}

A study was conducted at the Institute of Guided Vocational Education among students of continuing education courses, as a result of which the influence of digital technologies on the quality of training of students of advanced training courses was established. The study involved 4 educational groups, the overall composition of which s has been divided into 2 groups. In the preparation of the first group of students of 45 people, the training was conducted in a more traditional way, without the introduction of advanced 
REVISTA DE LA UNIVERSIDAD DEL ZULIA. $3^{a}$ época. Año 11 N 31, 2020 Ekaterina V. Vezetiu et al. /// Digital technologies in the organization of the educational process ...450-460

DOI: http://dx.doi.org/10.46925//rdluz.31.28

digital technologies. In the training of the second group (44 people), various digital technologies were actively used.

In the process of learning a second group of trainees s "Actual problems of modern education", "Management in Education", they have been used telecommunications technology, embedded technology chat bot technology Big the Data.

Telecommunication technologies were one of the first to be introduced into the educational process. The use of computer technology and multimedia training tools are actively used in the process of advanced training. For example, students use Skype, forums and chats, discussing educational issues at a distance from each other.

The chat-bot provided effective feedback from teachers to course participants.

Virtual reality technologies made it possible to create models of objects and processes outside of classroom conditions, providing students with a high degree of mobility when studying material.

When mastering the training material at a remote distance, students of the courses "Actual Problems of Modern Education" and "Management in Education" made videoconference calls using Adobe Connect. To increase the visibility of the lectures, the layout of the video communication desktop was set up, the information output modules were scaled, which made it possible to focus the students on the means of accompanying the lecture. Through the use of video-conferencing, the creative component of the educational process increased, not limiting the teacher to the scope of the usual presentation, which usually accompanies face-to-face lectures. At lectures in the classroom, document cameras were used. The teacher displayed the image of the original documents and printed teaching materials.

At continuing education courses for teachers "Actual Problems of Modern Education", "Management in Education", students created training materials and test assignments using electronic services. For example, the program Kahoot is used to create quizzes, tests and surveys. You can answer questions from any device: a mobile phone, tablet, laptop or personal computer with access to the Internet. Students used the tools of electronic educational platforms on which lectures and additional material were located for a deeper study of the course. To carry out the control, we used test and creative tasks that were performed in an electronic environment. 
REVISTA DE LA UNIVERSIDAD DEL ZULIA. 3e época. Año 11 N 31, 2020

Ekaterina V. Vezetiu et al. /// Digital technologies in the organization of the educational process ...450-460

DOI: http://dx.doi.org/10.46925//rdluz.31.28

As part of the implementation of creative projects, students created videos using virtual laboratories.

With the help of Big Data, teachers could track the educational process of the entire group of students and each student individually.

Students of both groups throughout the training were engaged in self-preparation of creative projects. The defense of the project was carried out at the final lesson.

Figure l presents the results of statistical processing of students' grades of two groups based on the results of project protection.

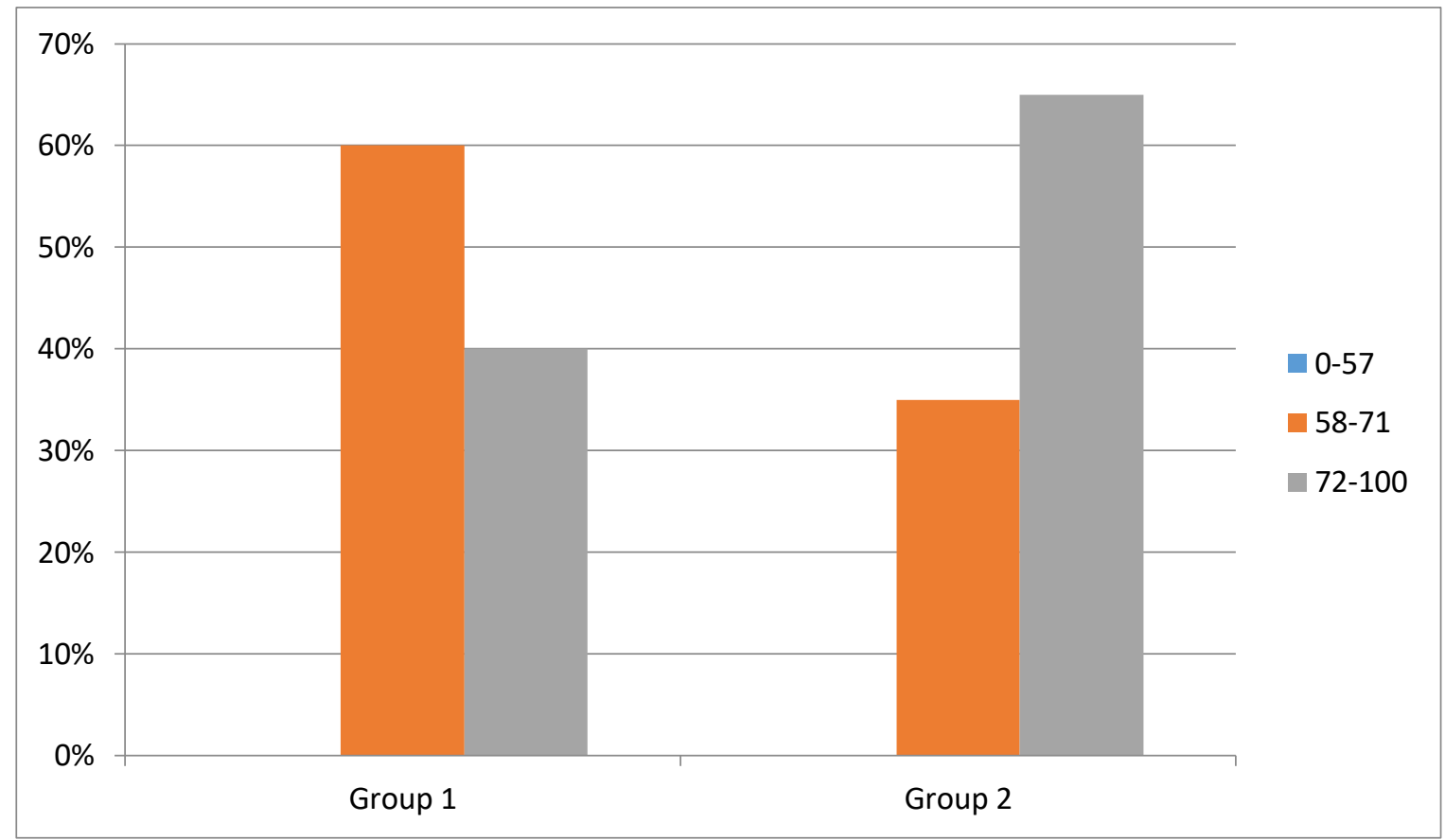

Fig. 1. The results of the defense of the final design work (as part of our study)

The second group of students whose training was carried out using digital technology has higher scores. From which it follows that digital technology helps to improve the quality of student training. We have conducted a survey among a listener to it in this group. Table 1 reflects issues for audience response.

An analysis of the results allows us to say that respondents note the importance of using digital technologies, $56 \%$ of respondents believe that these technologies help increase the pace of the project, select relevant information and prepare the project as a whole. Teachers note that they would like to use digital technology in organizing the learning process. 
REVISTA DE LA UNIVERSIDAD DEL ZULIA. $3^{a}$ época. Año 11 N 31, 2020

Ekaterina V. Vezetiu et al. /// Digital technologies in the organization of the educational process ...450-460

DOI: http://dx.doi.org/10.46925//rdluz.31.28

Figure 3 shows the digital tools that advanced training students used during project preparation.

Table 1. Survey of trainees (as part of our study)

\begin{tabular}{|l|l|l|}
\hline 1 & $\begin{array}{l}\text { Do you think that digital technology contributed } \\
\text { to the successful preparation of the project? }\end{array}$ & $\begin{array}{l}\text { - Yes; } \\
\text { - Rather yes, than no; } \\
\text { - Rather no, than yes; } \\
\text { - No }\end{array}$ \\
\hline 2 & $\begin{array}{l}\text { What digital tools did you use during the } \\
\text { preparation of the project? }\end{array}$ & $\begin{array}{l}\text { - electronic textbooks and } \\
\text { manuals; } \\
\text { - online courses; } \\
\text { - digital library; } \\
\text { - virtual laboratories; } \\
\text { - multimedia equipment; } \\
\text { - electronic educational } \\
\text { platforms; } \\
\text { - document cameras; } \\
\text { - interactive whiteboards; } \\
\text { - chat-bots }\end{array}$ \\
\hline
\end{tabular}

The results of statistical processing of the survey are shown in Figures 2 and 3.

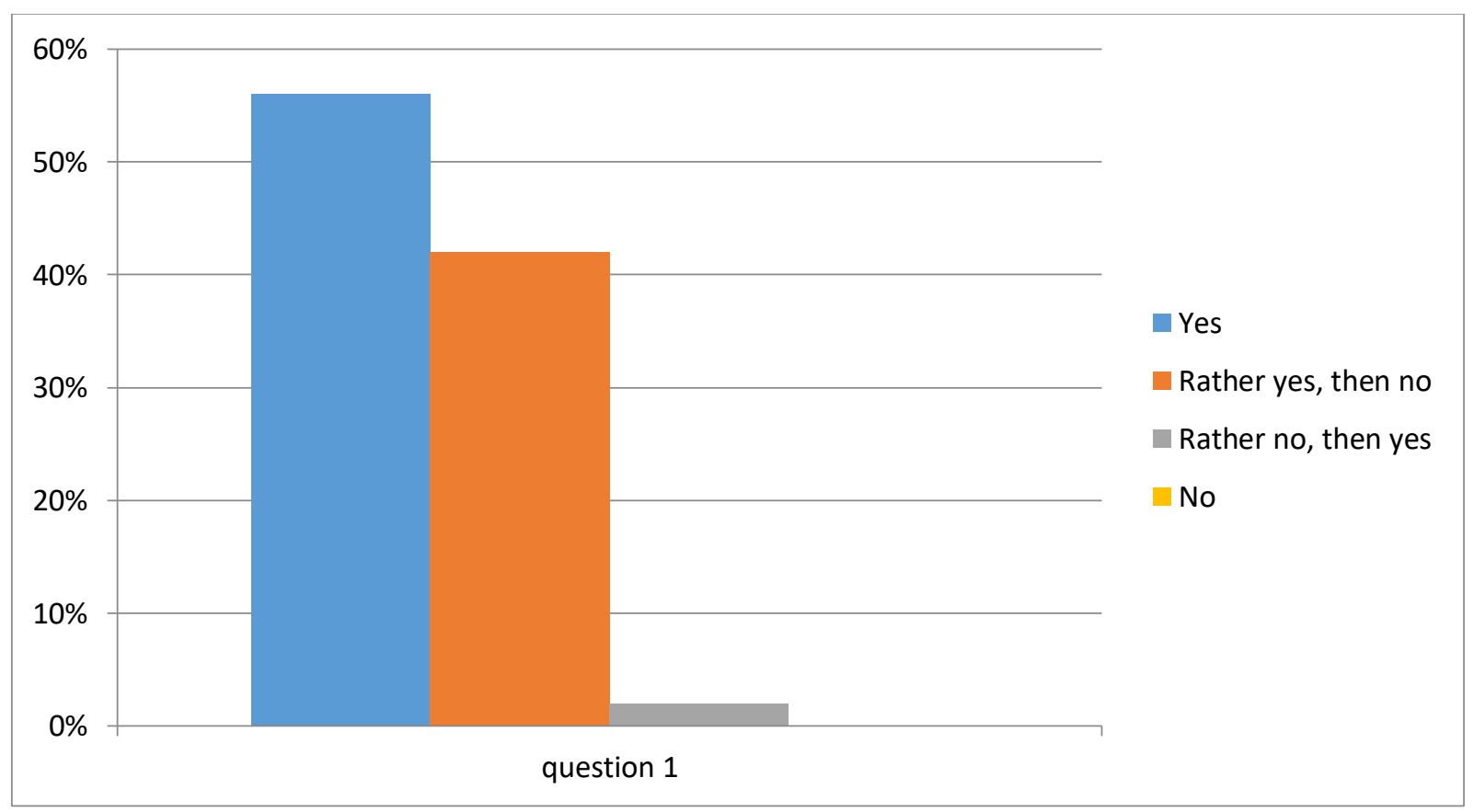

Fig. 2. The results of statistical processing of a survey of students to determine the impact of digital technology on the success of the project (as part of our study) 
REVISTA DE LA UNIVERSIDAD DEL ZULIA. $3^{a}$ época. Año 11 N 31, 2020

Ekaterina V. Vezetiu et al. /// Digital technologies in the organization of the educational process ...450-460

DOI: http://dx.doi.org/10.46925//rdluz.31.28

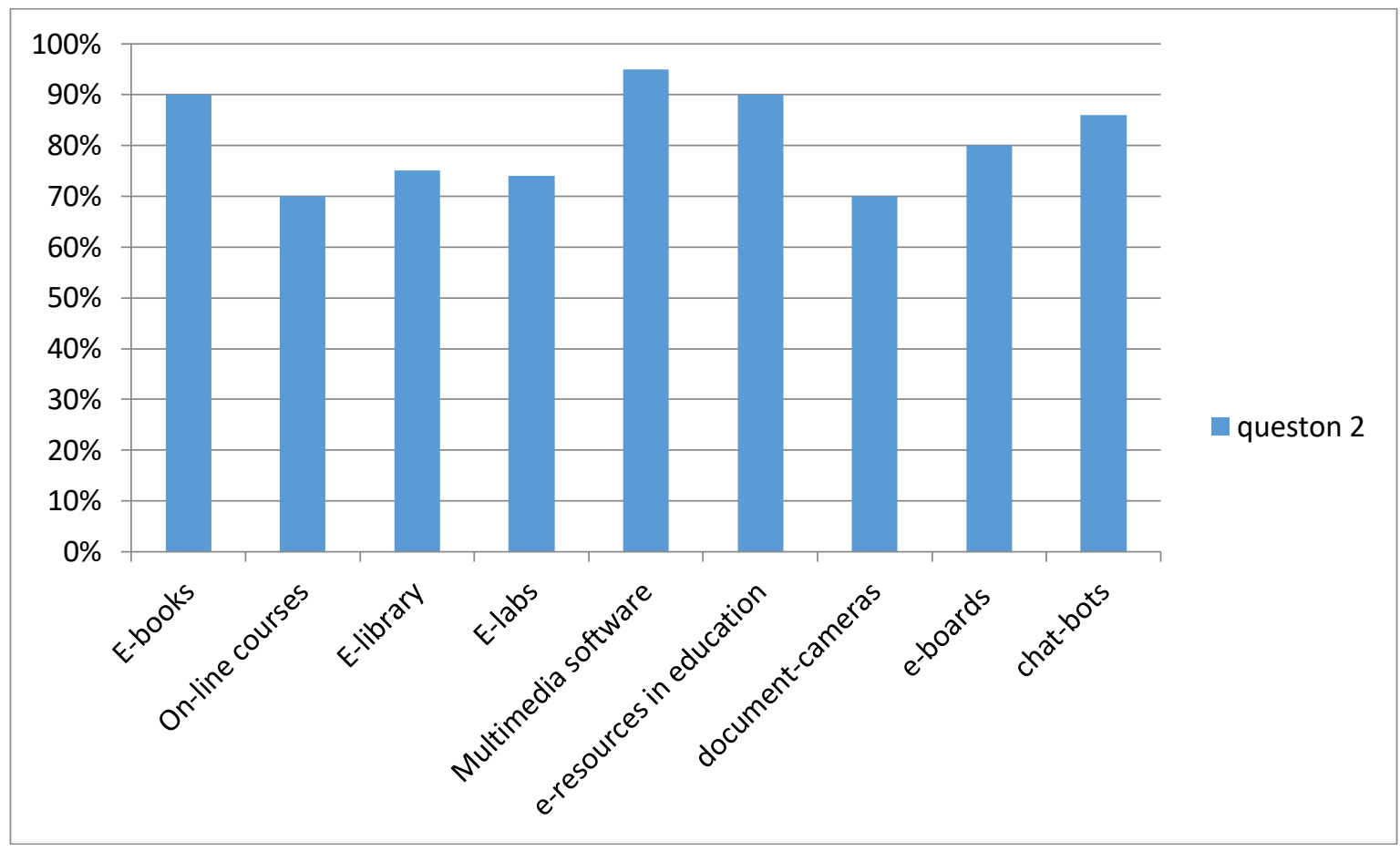

Fig. 3. Qi Frova e-tool is used by students during the preparation of the project (as part of our study)

In the process of preparing the project, students used a large number of electronic tools that contribute to the selection of relevant information, maintaining mobility (preparation could be carried out remotely, anywhere and anytime), organizing effective interaction of students and students with the teacher). It is noted that digital technology can make the process of preparing more mobile. At the same time, the quality of training not only does not decrease, but becomes higher.

The active use of digital learning technologies by teachers has improved performance. Analysis of the results suggests that the respondents see a need to continue organization of students' preparation with using digital technology.

\section{Conclusions}

The paper considers constructing e learning process with the use of digital technologies. The analysis of the influence of digital technologies on the quality of training of students of continuing education courses is conducted. The study revealed the wide possibilities of digital technologies in organizing the process of training students of advanced 
REVISTA DE LA UNIVERSIDAD DEL ZULIA. $3^{a}$ época. Año 11 N 31, 2020 Ekaterina V. Vezetiu et al. /// Digital technologies in the organization of the educational process ...450-460

DOI: http://dx.doi.org/10.46925//rdluz.31.28

training courses of the Institute of Guided Professional Education. The listeners, in whose training digital technologies were used, were able to use a large number of electronic tools to independently prepare the project work, contributing to a more intensive task. As students themselves learn, digital technologies help increase the pace of the project, select relevant information and prepare the project as a whole. At the same time, the quality of training not only does not decrease, but becomes higher.

\section{References}

Aleksieienko-Lemovska, L.V. (2019). The activity approach as a basis for preschool teachers' methodological activities, Humanitarian Balkan Research, 3, 4(6), 10-14.

Andriushchenko, T. K., (2018). Personal aspects of pedagogue's innovative culture, Scientific Vector of the Balkans, 1, 13-16.

Bulayeva, M.N., Aleshugina, Ye.A., Maksimova, K.A. (2019). Modeling of the process of formation competence of teachers in university. Baltiyskiy gumanitarnyy zhurnal (Baltic Humanitarian Journal), 8, 3 (28), 21-24. (in Russ.).

Chirva, A.N., Chirva, O.G. (2018). Contents and method of professionally oriented training of informatic disciplines of future teachers of technologies. Scientific Vector of the Balkans, 1, 2731.

Cirdan, A.P. (2019). Innovative technologies of professional training of future economists in the system of continuous education. Humanitarian Balkan Research, 2(4), 27-30.

Donetskova, O.YU. (2019). Modernization of the modern education system in Russia. Baltiyskiy gumanitarnyy zhurnal (Baltic Humanitarian Journal), 8, 2 (27), 37-39. (in Russ.).

Filchenkova, I.F. (2019). Educational management of innovative activity of teachers as an object of pedagogical research. Vestnik Mininskogo universiteta (Vestnik of Minin University), 2019. 7 (4), 3. (in Russ.).

Grigoriev S. G., Shabunina V. A., Tsarapkina Ju. M., Dunaeva N. V. (2019). Electronic library system as a means of self-development of students of digital generation $Z$ (on the example of studying the course "Basics of the counselor activity") - Scientific and technical libraries. 2019. No. 7. Pp. 78-99. 29.

Myalkina, E.V. (2019). Diagnostics of the education quality in the higher educational institution. Vestnik Mininskogo universiteta (Vestnik of Minin University), 7, (3), 4. (in Russ.)

Oros, I.I. (2018) The role of international connections in the development of the adult education system. Humanitarian Balkan Research, 1, 57-59. 
REVISTA DE LA UNIVERSIDAD DEL ZULIA. 3e época. Año 11 N 31, 2020 Ekaterina V. Vezetiu et al. /// Digital technologies in the organization of the educational process ...450-460

DOI: http://dx.doi.org/10.46925//rdluz.31.28

Osadchenko, I.I. (2019). Key concepts of situational training technology in preparing future teachers. Scientific Vector of the Balkans, 1 (3), 46-49.

Pichugina, G.A., Bondarchuk, A.I. (2019). Structure of the training case in the organization of the educational process. Humanitarian Balkan Research, 2(4), 5-7.

Pisarenko, D. A. (2019). Evaluation of extracurricular activities of university students with a competency-based approach, Scientific Vector of the Balkans, 3, 3 (5), 37-40.

Pliushch, V.M. (2018). Independent work of students as a factor of improving education quality. Balkan Scientific Review, 1, 69-71.

Raven, J. (2017). Education and Sociocybernetics, Azimut nauchnykh issledovaniy (Azimuth of Scientific Researches: Economics and Management), 6, 3 (20), 289-297.

Tsarapkina, Ju.M., Petrova, M.M., Mironov, A.G., Morozova, I.M., Shustova, O.B. (2019a). Robotics as a basis for Informatization of education in children's health camp. Amazonia Investiga, 8 (20).

Tsarapkina, Ju. M., Dunaeva, N. V., Kireicheva, A. M. (2019b). Application of BYOD technology in education on the example of Lecture Racing mobile application, Informatika $i$ obrazovanie - Informatics and Education, 9 (308), 56-64.

Vaganova, O.I., Ilyashenko, L.I., Smirnova, Zh.V., Bystrova, N.V., Kaznacheeva, S.N. (2019a) Students' creative abilities development in higher educational institution. Amazonia Investiga, $8(22), 701-710$

Vaganova, O.I., Rudenko, I.V., Markova, S.M., Smirnova, Zh.V., Kutepov, M.M. (2019b) The use of educational video materials in educational process of a higher educational institution. Amazonia Investiga, 8 (22), 216-222.

Vaganova, O.I., Livshits, Yu.A., Aleshugina, E.A., Smirnova Zh.V., Kutepova L.I. (2019c) Experience in developing electronic glossary in a higher education institution. Amazonia Investiga, 8 (22), 247-253. 